\title{
MODELS FOR INNOVATION DEVELOPMENT OF RURAL TERRITORIES BASED ON INFRASTRUCTURE DEVELOPMENT
}

\author{
Larysa Kalachevska ${ }^{1}$ \\ Sumy National Agrarian University, Ukraine
}

\begin{abstract}
The research subject is an aggregate of theoretic and methodical grounds for choice and organization of rural development innovation models based on infrastructure development, taking into consideration the world experience. Methodological and theoretical ground for the research is a systematic approach for studying socialeconomic and ecologic phenomena and processes under the market conditions. In order to solve some tasks, there are used several methods: abstract-logical method to determine the conception and methods of analysis and synthesis. The aim of the research is to study the models for innovation development of rural territories based on infrastructure development. Conclusions. Segregate scientific approaches to form the model of rural economy are ruralism and neoruralism. Ruralism is a way of thinking and idea representing ruralisation in the human community, the development of which is focused on securing food supply and needs of those who live and work in rural areas. Neoruralism is a multifunctional social-economic system, which is focused on broadening of powers for united territorial communities. The rural economy here is an open system, focused on securing rural inhabitants welfare. The idea that agricultural changes in terms of modern tendencies and effective models of rural development, especially in the sphere of agricultural modernization, as a ground for its sustaining power, improvement of competitive ability for agricultural production and to meet the WTO Ukrainian member requirements is proved. Strategic benchmarks for Ukrainian rural areas in accordance with the requirements of Europe 2020 strategy are smart development - balanced development of the economy and social sphere; constant development - abide by scientifically proved norms; inclusive development - taking into consideration social standards for development. Special institutions determining law institutional mechanism of innovation development are very important for the revival of rural areas and infrastructure development.
\end{abstract}

Key words: development model, rural areas, estimation, infrastructure, social sphere.

JEL Classification: F140, Q180

\section{Introduction}

Rural areas are the important element of life in any country, developing under the conditions of market economy, they have a great economic, natural, demographic, and socio-cultural potential. Utilization of such potential in many ways determines the development of certain regions. That is why any country must consider the development of rural areas as an important step, not only for the improvement of agricultural productivity but also for increasing of GDP in the whole. We must also determine the development of rural areas choosing a particular model able to solve the existing tasks.

The existing model for agrarian sector development, where large agrarian holdings have the dominant role, has negative ecologic and social effect. Ineffective utilization of key asset - land is in the first place. Large agrarian holdings renting more than a half of all

Corresponding author:

${ }^{1}$ Department of FEA Management and Eurointegration, Sumy National Agrarian University.

E-mail: likalachevska@gmail.com agricultural lands grow only highly productive cultures, without following crop rotation measures, they use great numbers of chemicals without application of organic fertilizers. Such technologies lead to soil fertility fall. Soils are vulnerable to water and wind erosion. Utilization of "monoculture" leads to accumulation of heavy metals, pesticides, and pathogenic agents in soil. Wrong crop rotation leads to large numbers of weeds and pests.

Practically all production of large agrarian holdings is exported as a raw material. So, producers do not get added value from procession and marketing. It damages agricultural complex, leads to increase in unemployment rates in rural areas and restrain the development of social and productive infrastructure.

Besides, holdings, having modern wide agricultural machinery, a number of storage facilities and resources for chemical fertilization, leave small farms and agricultural enterprises as non-competitive. It leads to a 
reduction in a number of such enterprises and decrease in production of food crops, grown on small farms. Holdings do not invest much in the development of rural infrastructure especially social and productive.

Taking into consideration the depression of rural areas, we consider the tendency to decrease in purchasing power for food products. It restrains the eco production, which is highly important in the formation of a healthy nation. Among the challenges of the agrarian sector is the lack of commercial, law, and market information needed by stakeholders, it restricts their investment activity. Unpredicted changes in taxation system also have a negative effect on the agrarian sector. All these points need to be urgently changed together with the implementation of new legislation considering the agrarian sector. Everything mentioned above needs new models for innovation development of rural areas based on infrastructure development

\section{Research and literature analysis}

Theoretical grounds for innovations in agrarian infrastructure development and theoretical and methodological paradigm of rural areas development and rural economy in particular have been studied by famous Ukrainian and foreign scientist. T. M. Lozynska has studied the institutional inefficiency of transformations in the agrarian sector (Lozynska, 2012). Tendencies, subjects, and prospects of reforming rural areas are the research subject of A. Yermolaiev, I. Klimenko, V. Yemets, S. Taran (Yermolaiev, 2015). Current state and prospects of international integration of agrarian sector have been studied by Y.O. Lupenko (Lupenko, 2015) and P. T. Sabluk (Sabluk, 2006). M. O. Baranovskyi has studied the rural areas in the context of the level of their development, transformational changes, and conceptual approaches (Baranovskyi, 2011). M. B. Polenkova studied the economic complex of rural areas and its integral aspect, in particular (Polenkova, 2013). A. V. Lisovyi studied methodological approaches to the assessment of rural areas in Ukraine and their need for innovation development and creation of infrastructure (Lisovyi, 2013). However, a great number of other points in innovation development for rural areas still demand a research work.

\section{Research materials}

Problems of rural areas are evident and if the situation gets worth, it will cause the danger to territorial balance. The characteristic feature of the process is dissolution of many locations from the map of Ukraine. As it is known, the reason for it is a crisis in the basic brunch of economy - agriculture. M. Baranovskyi studying the conceptual approaches for reformation of agricultural sector, mentioned that Ukraine for many years had one way of rural development, despite its agrarian potential, it had agrarian tendency without development of any other productions (Baranovskyi, 2012). The mentioned above facts show the need for theoretical and methodological research in the sphere of systematic development for rural areas with innovation models adapted to modern challenges.

Scientific researches of Ukrainian and foreign scientists, based on classic approaches to agricultural economics concerning the specifics of native agrarian sector development became the ground for models of agricultural development. Scientific researches of agrarian economists are important for further research work and creation of strategic vectors for further development of rural areas. The mentioned researches give the opportunity to separate two development models for rural areas based on innovations: ruralism and neoruralism (Fig. 1).

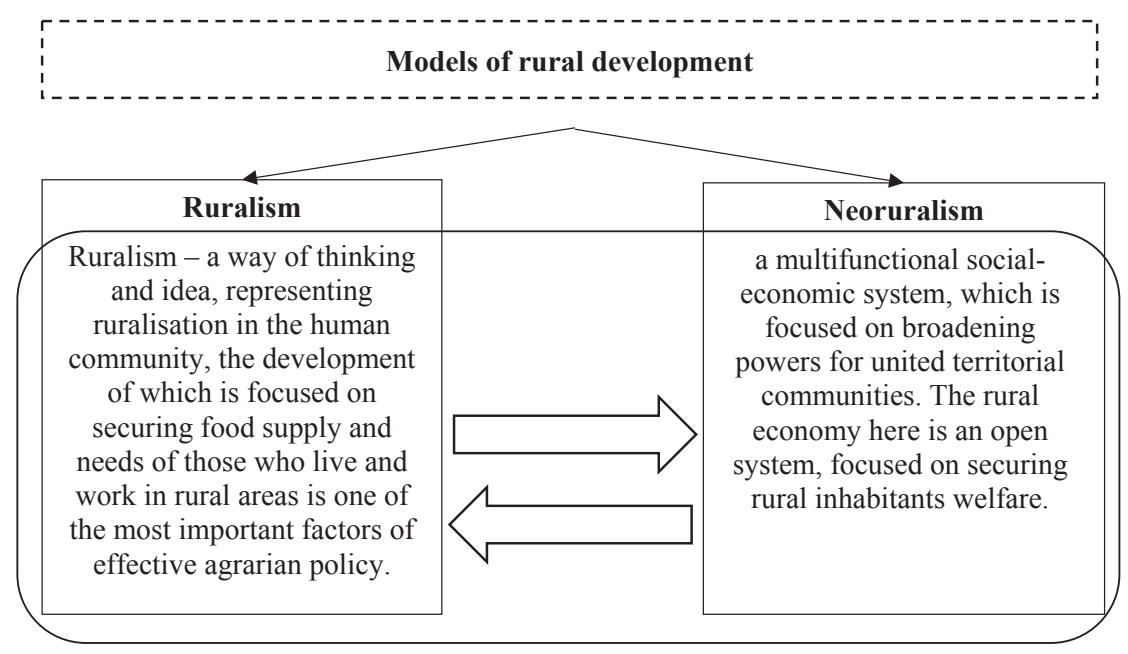

Fig. 1. Scientific approaches to form the model of the rural economy according to the principles of ruralism and neoruralism

Source: the author's research 
Theoretical and methodological approaches of ruralism and neoruralism have several levels: global and national. Studies of the global level analyse the points of natural, spiritual, and economic development of rural areas under the conditions of modern challenges connected with the changes of the world markets, growing food supply problems and urbanization. National level studies specific characteristics of a particular country, its resources, peculiarities of production, and models of development. Neoruralism, extended under the conditions of decentralization and broadening of powers for united territorial communities, having enough financial resources and the ability to use active assets, is concentrated in rural areas, new communities can solve a great number of economic, ecologic, and social problems.

Despite the number of the researches, the formation of the new socially oriented economy is an urgent problem and needs further research work. P. M. Matvieiev, studying ecologic and economic grounds for the formation of effective agricultural production, states that the key branch of the real economy sector is agriculture, effective and rational development of which is a guarantee for food and ecological safety of any country (Matvieiev, 2014).A. V. Lisovyi, studying the methodical approaches to assessment of rural areas and the need of innovation and infrastructure development, proved that agriculture gradually becomes the indicator of economic development, showing a good economic efficiency of agricultural production, steady increase of innovation ability and investment prospects (Lisovyi, 2007).

Current state and challenges of agrarian land transformations in Ukraine have been studied by A. Yurchenko. Taking into consideration the fact that agriculture is an important factor of welfare, the author says that there is a need for a certain model providing steady development of the sector. Ukraine due to existing soil resources and favourable climatic conditions is highly competitive on the world market (Yurchenko, 2015). An important part of steady development for rural areas is effective functioning of agriculture, being presented in multifunctional production (Fig. 2).

O. M. Borodina, describing the rural development policy based on united communities in Ukraine proves that multifunctional conception is a methodological ground for strategies for the agrarian sector in many countries of the world and in European Union in particular (Borodina, 2015).

Under the conditions of globalization and growing competition among the world producers of agricultural

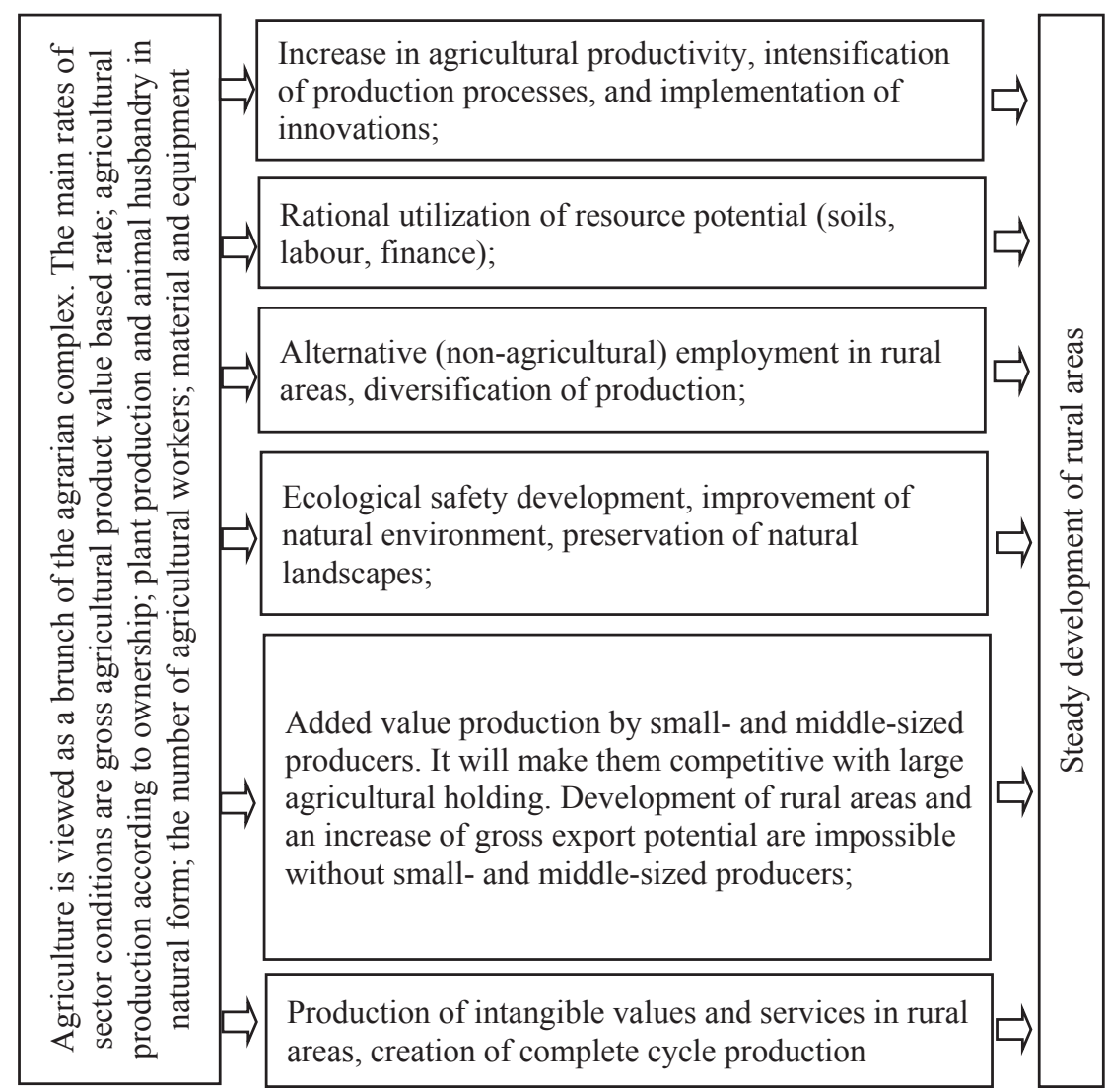

Fig. 2. Parts of a steady agricultural development as a system-forming part of the agrarian sector

Source: the author's research 
production, it is important to develop models of future development for the agrarian sector and rural areas, with a system of assessment for it (Fig. 3).

Grouping of indicators allows forming four groups, depending on their functional purpose: economic characterize economic effectiveness, institutional characterize the level of legislation, social - characterize social effectiveness, ecological - characterize the level of the ecological environment. In order to secure the development of rural areas, according to neorural model, it is necessary to develop and confirm the long-term oriented plan of rural development. One of the most important parts of this process is scientific and research work. It contains initiation for development, making the idea popular, the creation of a work group to provide scientific researches. Scientific research work, in its turn, is held in two directions. The first, the assessment of territorial competitive ability, the second is an assessment of competitive advantages and critical challenges of territorial development. The final point of the research work is in discussion and confirmation of the research results.
The planning system has three-way activity, devoted to the development of systematic, special multisectoral programs and projects based on competitive advantages. Here we can mention human resources, spatial planning, and electronic government. The development of programs involves a power supply, environment protection, modernization of living conditions. In Ukraine realization of such incentives is a problem because of the lack of financial support. Agrarian sector of EU depends on donations and gets lots of financial resources for the development. Decentralization is one of the reforming measures providing accumulation of the financial resources needed. The process of government decentralization and reformation of local authorities is a priority of modern Ukrainian policy. It must have a positive effect on the development of rural areas (Fig. 4).

Under the conditions of decentralization and reformation of the management system and growing of agrarian sector, it is impossible to do so without the development of infrastructure. It is important now to form a united
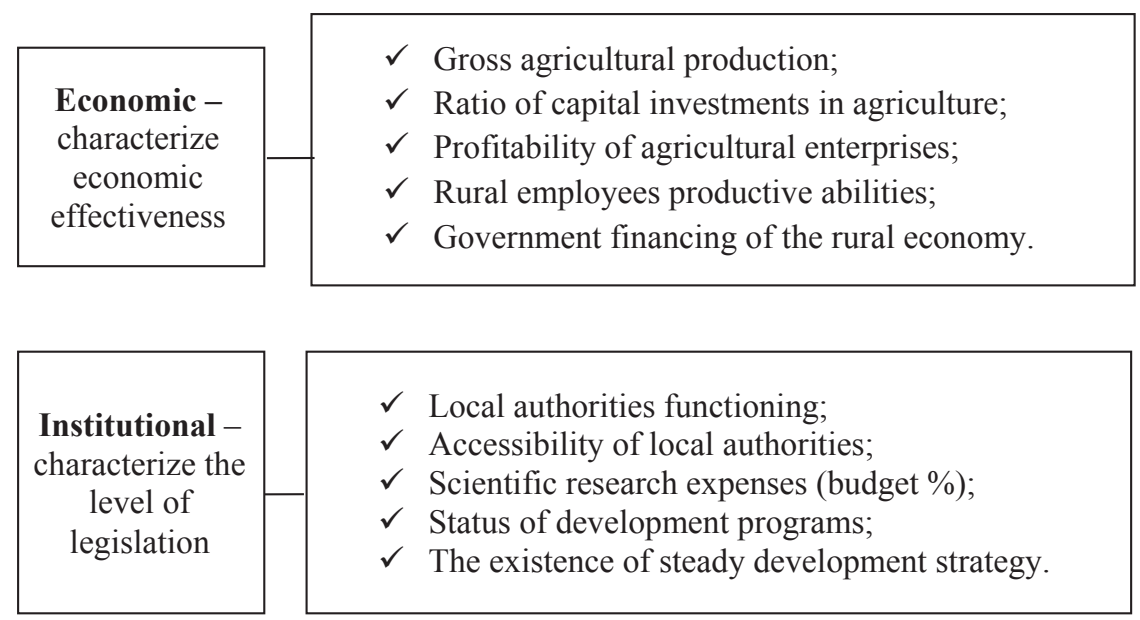

$\left.\begin{array}{|c|}\text { Social - } \\
\text { characterize } \\
\text { social } \\
\text { effectiveness }\end{array}\right] \quad$\begin{tabular}{lll|}
\hline & $\checkmark$ & Income-expenses relation; \\
& $\checkmark$ & Level of rural unemployment; \\
& $\checkmark$ & Budget healthcare expenses; \\
& $\checkmark$ & Hospital accessibility for rural inhabitants; \\
& $\checkmark$ & Internet and media accessibility. \\
\hline
\end{tabular}

\begin{tabular}{|c|c|}
\hline $\begin{array}{c}\text { Ecological - } \\
\text { characterize the } \\
\text { level of ecologic } \\
\text { environment }\end{array}$ & $\begin{array}{ll}\checkmark & \text { Expenses to decrease air pollution; } \\
\checkmark & \text { Expenses for ecosystem restoration; } \\
\checkmark & \text { Expenses for measures of biodiversity } \\
& \text { conservation; } \\
\checkmark & \text { The amount of waste from stationary and mobile } \\
& \text { sources of pollution per 1 person; } \\
\checkmark & \text { The rate of biotechnologies utilization. }\end{array}$ \\
\hline
\end{tabular}

Fig. 3. Set of indicators for the assessment of models for rural development

Source: the author's research 


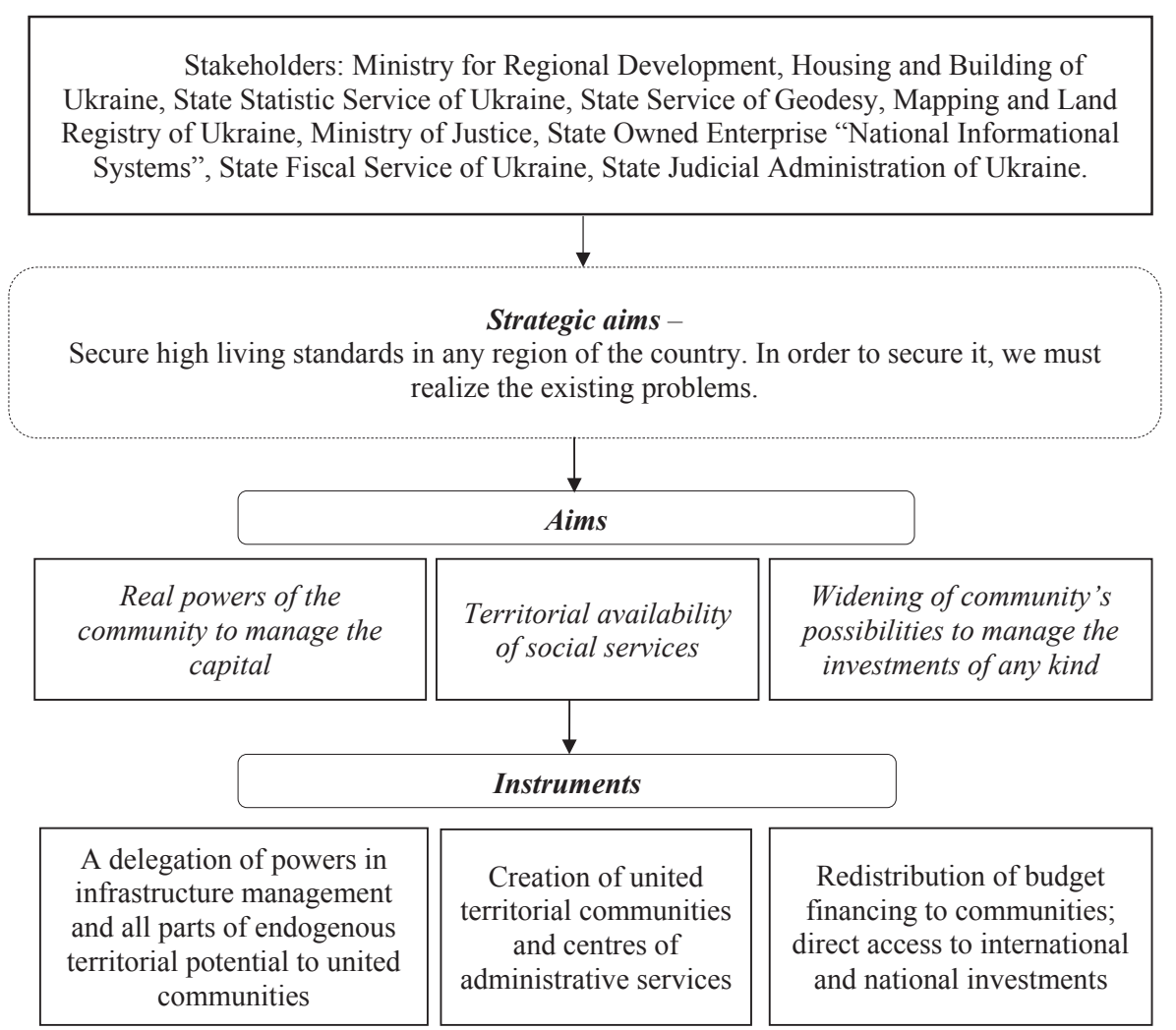

Fig. 4. Aims for the development of rural areas under the conditions of decentralization and widening of united territorial communities powers

Source: the author's research

organizational, economic, finance, investment and logistic system of development. All of them are closely connected and form the united system of infrastructure development. Having a base in the neorural idea, decentralization gave the local authorities an opportunity to improve the conditions for local business. The principle is easy to understand the better conditions local enterprises have, the better financing a local budget has.

\section{Conclusions}

The model of decentralization chosen, having a base in the neorural idea, is an important step of rural areas development. First steps in uniting the communities have positive results; today we need a special strategy and system of problem-solving for further development.

First of all, we must consider the functions of rural territories. It contains: productive-economic, sanative-recreational, environment protection and social functions. The productive-economic function is of a global character, as it is a decision for Food Safety Program of our country, and provides the rural community with the inputs and clear legislation in the market for agricultural production.

Together with economic problems, we need to solve ecologic problems; these ecologic problems contain sanative-recreational and environmental protection.
Ecotourism must be an integral part of rural development. Environment protection and rational utilization of natural resources must be a dominant function in rural areas.

Social content is one more important point of rural functioning. Here is the development of infrastructure, whole year employment of rural inhabitants, the creation of conditions for labour and rest needed for educational, cultural, and health development.

In order to solve these problems, we need to proceed in the revival of rural territories and create conditions for steady development. But first of all, we must consider the social purposes for rural areas. All above mentioned requires control of recourses utilization, especially for the agricultural lands, increase soil productivity and protection of the environment.

The main aims of rural development, under the conditions of decentralization model, are real managing power of united communities, making the social services available and others. According to the research data, monitoring of the process of decentralization, we have some positive results. As of 17 October 2017, 665 united territorial communities have been created. 252 communities have the desire to run in the elections, it is a positive impulse, showing a good performance in the development of rural areas, having a positive effect on the social and productive sphere. 


\section{References:}

Baranovskyi M. (2012) Kontseptualni pidkhody do reformuvannia silskoho sektora Ukrainy [Conceptual approaches to the reforming of rural sector of Ukraine] - Nizhyn Mykola Gogol State University Publishers: pp. 29-30. [in Ukrainian]

Borodina O. (2015) Polityka silskoho rozvytku na bazi hromad v Ukraini : naukova dopovid. [Community-based rural development policy in Ukraine: Scientific Report] National Academy of Sciences of Ukraine. Kyiv: pp. 47. [in Ukrainian]

Yermolaiev A. (2015) Ahrarnyi sektor Ukrainy: tendentsii, subiekty, perspektyvy reformuvannia [Agrarian sector of Ukraine: trends, subjects, prospects for reforming]. Kyiv: ISD: 28 p. [in Ukrainian]

Lisovyi A. (2007) Metodychni pidkhody do otsiniuvannia silskykh terytorii Ukrainy [Methodological approaches to the assessment of rural territories in Ukraine]. Ekonomika APK - Economics of AIC (8): pp. 123-130. [in Ukrainian]

Lozynska T. (2012) Instytutsiina neefektyvnist transformatsii v ahrarnomu sektori ekonomiky [Institutional inefficiency of transformations in the agrarian sector of economics]. Scientific works of Poltava State Agrarian Academy (5): pp. 163-169. [in Ukrainian]

Lupenko Yu. (2015) Suchasnyi stan ta perspektyvy mizhnarodnoi intehratsii ahrarnoho sektoru Ukrainy: zavdannia ahroekonomichnoi nauky [Current state and prospects of international integration of agrarian sector of Ukraine: problems of agroeconomic science]. Ekonomika APK - Economics of AIC (6): pp. 6-11. [in Ukrainian]

Matvieiev P. (2014) Ekoloho-ekonomichni zasady formuvannia silskohospodarskykh zemlevolodin i zemlekorystuvan [Ecological and economic principles of agricultural land holdings formation]: dissertation of candidate of economic sciences, Kharkiv: 358 p. [in Ukrainian]

Polenkova M. (2013) Hospodarskyi kompleks silskykh terytorii: intehralnyi aspect [Economic complex of rural territories: an integral aspect]. Molodyi vchenyi - Young scientist 2(02): pp. 32-39. [in Ukrainian]

Sabluk P. (2006) Rozvytok silskykh terytorii - zaporuka vidrodzhennia ahrarnoi Ukrainy [Development of rural territories - a guarantee of agrarian Ukraine revival]. Visnyk ahrarnoi nauky - Bulletin of Agrarian Sciences (5): pp. 21-23. [in Ukrainian]

Yurchenko A. (2015) Suchasnyi stan ta problemy zemelnykh transformatsii v ahrarnii sferi Ukrainy [Current state and problems of land transformations in the agrarian sector of Ukraine]. Zemlevporiadnyi visnyk - Bulletin of land management (12): pp. 28-31. [in Ukrainian] 